\title{
Principles of Mercy and Peace in Islam
}

\author{
Dr. Youssef Mezrigui \\ Higher Institute of Applied Languages and Computer Science of Béja, University of Jendouba, Tunisia \\ Email: mezriguiyuceph@yahoo.fr
}

\section{Doi:10.5901/mjss.2015.v6n4s3p547}

\section{Abstract}

The background of this paper relates to the insulting and mocking depictions of Prophet Muhammad (peace and blessings of Allah be upon him) that were published by a number of European print media, as well as to 'Charlie Hebdo' incident, the terrorist attack that took place in Tunis on Bardo Museum on March 18, 2015, and the practices of the so-called "Islamic State" in some Arab regions. On this basis, therefore, and relying on Qur'an ${ }^{1}$ and Sunnah², the two major sources of Shariah (Islamic law and jurisprudence), and equally on some Muslim scholars' thoughts, the paper aims to serve, on the one hand, as a conclusive evidence that the deeds of those who act in diverse ways against the principles and teachings of Qur'an and Sunnah believing mistakenly that they are in a right Islamic path have nothing to do with Islam, but might rather defame it and its followers. On the other hand, the paper intends to function as a reply to anti-lslamic practices and islamophobic ideologies on the part of certain non-Muslim communities and organizations demonstrating that Islam is a religion of mercy and peace. This distinguishing characteristic underlies a number of principles and moral values which constitute the essence of good human relationships which Islam has had every intention of maintaining between all the peoples the world over.

Keywords: Islam; Qur'an; Hadith; mercy; peace; human relationships

\section{Introduction}

The first matter that one ought to know and clearly understand about Islam is what the name of this religion signifies. The word Islam means submission or surrender of one's will to Allah (Philips, 2012). Islam as an Arabic word derives from the two synonymous Arabic words salam and silm, which both mean peace in English. The two aforementioned meanings of Islam are equally conveyed in an electronic article: "The Arabic word Islam stands for submission or peace." Religiously speaking, the article goes on explaining that the term denotes the "peace that reaches out to one when one completely submits oneself to the will of Almighty God. This is achieved only when the individual acts in accordance with the direction of his Creator in all spheres of life" ("What is Islam?" n.d., parag.1). Alghul (2009) could be claimed to give a more comprehensive definition of Islam. He quotes Sinanoglu as stating the root of the word Islam, silm, refers to "making peace, being in a mutually peaceful environment, greetings, rescue, safety, being secure, finding peace, reaching salvation and well-being or being far from danger, attaining goodness, comfort and favor, keeping away from troubles and disasters, submitting the self and obeying, respect, [and] being far from wrong."

Peace as one basic meaning of Islam is also exhibited through the behavior of a true Muslim, which is described in a prophetic Hadith. It was narrated on the authority of Jabir that he heard Prophet Muhammad (peace and blessings of Allah be upon him) say: "A Muslim is one from whose tongue and hand people are safe" (Sahih Muslim; Book 001, Hadith number 65). On the basis of what is examined earlier, and hinging on many Qur'anic verses and prophetic Hadiths, it could be affirmed that Islam has always sought peace; it has never advocated terrorism or any form of violence, and has always been against extremism, excessiveness, and immoderation. It has constantly underscored the necessity of establishing good human relationships between individuals, communities, and countries in a violencefree environment. Allah, the Exalted, says, "Allah does not forbid you with regard to those who have not fought you for your religion, and have not driven you out of your homes, from dealing kindly and justly with them. Verily, Allah loves those who are just" (Qur'an, 60: 8). In a similar context, Ibrahim (1997) held that "Muslims follow a religion of peace, mercy, and forgiveness, and the vast majority have nothing to do with the violent events some have associated with

\footnotetext{
${ }^{1}$ With regard to the translation of the Qur'anic verses into English, the author of the paper relied on Aberry (1983), Ali (1996), and AlHilali \& Khan (1998).

${ }^{2}$ As concerns the translation of the prophetic Hadiths into English, the author of the paper relied on Al-Khattab (2008), Al-Khattab (2012), Khan (1997), and Siddiqui (2005).
} 
Muslims. If an individual Muslim were to commit an act of terrorism, this person would be guilty of violating the laws of Islam." Duell (2014) reported that Pope Francis affirmed that "equating Islam with violence was wrong and called on Muslim leaders to issue a global condemnation of terrorism to help dispel the stereotype". In this frame of reference, Iftikhar (2014) contended that certain so-called Muslim organizations who claim to be killing in the name of Islam are, in reality, completely defiling its essence, and that the extremists and militants who attempt to hide behind the veneer of this religion are, in fact, openly violating many of its kernel precepts.

In this setting, it is worthy of note that where Charlie Hebdo incident is concerned, and although publishing the caricatures intended to make fun of Prophet Muhammad (peace and blessings of Allah be upon him), who was sent by Allah as mercy to all humankind, is a very serious crime which very deeply offended 1.8 billion Muslims all over the world, and despite the fact that the assault was a reaction, Muslims around the globe, notably scholars, imams and cultivated people did not approve of such a reaction at all, in view of the fact that it contradicts the teachings of Islam, among which are tolerance and patience with other people's various types of harm. For instance, as a response to those caricatures, it was reported that "Dublin-based Shaykh Umar Al-Qadri calls for Irish Muslims not to allow hatred creep into their hearts, [but to] react with patience, tolerance, gentleness and mercy." He, however, has equally prompted Muslims to communicate their feelings and anger to people of their acquaintance, in particular those of different faiths ("Muslim communities share guidelines," 2015). Haneef (1995), in turn, stated that "self-control in governing one's temper is very strongly stressed, and forbearance and making allowances for others' faults are enjoined." She added that in case of a personal injury, and although retaliation is allowed, it is advisable for a Muslim person to forgive the harm for the sake of God out of mercy and compassion to the one who has caused it.

Reacting to other people's harm with patience, tolerance, gentleness, and mercy instead of resorting to retaliation is among the noble precepts of Islam, which can certainly contribute to maintaining peace, and avoiding conflicts, terrorist actions, and even wars. In a number of Qur'anic verses, Allah - among whose Most Beautiful Names are the Pardoner and the Oft-Forgiving - commands us to be patient, tolerant and not pay back evil with evil: "Those who patiently persevere, seeking the countenance of their Lord; establish regular prayers; spend out of the gifts we have bestowed for their sustenance secretly and openly; and turn off evil with good: for such there is the final attainment of the eternal home" (Qur'an, 13: 22). Allah, the Almighty, also says, "Repel evil with that which is best; we are best-acquainted with the things they utter" (Qur'an, 23: 96). Ali (1996, p. 859) commented on the very principle making the point that whether people speak evil of you, in your presence or behind your back, or do evil to you in either of those ways, all is known to Allah. It is not for you to punish (to retaliate). Your best course is not to do evil in your turn, but to do what will best repel the evil. Two evils do not make a good.

Psychologically speaking, resorting to violence in certain situations is not an aspect of strength, but it is an indicator of weakness, by reason of the inability of an opponent to solve a problem or settle a disagreement with others by means of convincing, peaceable ways. Roughly, in a similar frame of reference, the Apostle of Allah (peace and blessings of Allah be upon him) said, "The strong person is not the good wrestler. Rather, the strong person is the one who controls himself when he is angry" (Sahih Al-Bukhari, Book 73, Hadith 135).

Another major problem that mankind has been suffering from is racism. Broadly, racism manifests itself in prejudice resulting from feeling or considering oneself better than or superior to others on the basis of color, race, gender, religion, social status, etc, and hence dealing with those who are deemed inferior and treating them in diverse ways of injustice. No wonder, such behavior brings about hatred, verbal and material violence, and violation of certain human rights; and all these can sometimes lead to terrorist acts, either on the part of racists or those who are victims of racism. In Islam, however, there is no place for racism. Equality in all the fields of life is guaranteed. A simile in a prophetic hadith, which is well-known among Muslims, clearly refers to social equality: all people are as equal as the teeth of a comb. Such equality is stressed in a number of Qur'anic verses. Allah, among whose Most Beautiful Names is the Just, says, "Verily, the noblest of you in the sight of Allah is the most pious. Truly, Allah is All-Knowing, All-Aware" (Qur'an, 49:13). This Qur'anic verse manifestly points to justice as one of the fundamental human rights. The only matter that differentiates between individuals is the extent to which a person is God-fearing.

Moten (2013) underlined the fact that "Islam, as a way of life, is most emphatic on the realization of justice as a goal to be achieved and an ideal to be sought." He added that the Holy Qur'an categorically "commands justice and the doing of good" (Qur'an, 16:90), and warns the believers not to allow "your rancor for a people to cause you to deal unjustly" (Qur'an, 5:8). In this framework, the author pointed out that there are many Qur'anic verses that stress the necessity of establishing justice, and reported that the word 'adl' meaning justice is mentioned 28 times in the Holy Qur'an; the equivalent word 'qist' meaning balance is cited 27 times; and the word 'mizan' signifying scale and its derivatives occur 23 times. In a similar regard, Ibrahim (1997) maintained that "God created human beings as equals who are to be distinguished from each other only on the basis of their faith and piety." Moten (2013), in turn, noted that "a 
content analysis of the Qur'an shows that it lays [great stress] on the realization of justice and conversely the eradication of injustice in society." The Messenger of Allah (peace and blessings of Allah be upon him) underscored this equality in his farewell sermon. Referring to such a sermon and one of its cardinal messages, Wafy (1998) observed: "Prophet Muhammad embodied the principles of Islam [...] saying:"

O people! Your God is one God, and your father is one father, for you are all descendants of Adam, and Adam was created from clay. The most honored of you in the sight of God is the most righteous of you. No Arab is superior to a non-Arab and no non-Arab is superior to an Arab. No dark-skinned man is superior to a fair-skinned man and no fairskinned man is superior to a dark-skinned man, except by his piety. I have declared this to you as God is my witness, and may those who are present inform those who are absent.

Justice, one of the precepts of Islam, is clearly expressed in a Qur'anic verse in which Allah, glory be to Him says, "Truly God commands you to give back trusts to those to whom they are due, and when you judge between people to judge with justice (Qur'an, 4: 58). Allah also says, "...and act justly. Truly, God loves those who are just" (Qur'an, 49: 9). Ibrahim (1997) pointed out that ever since the era of Prophet Muhammad (peace and blessings of Allah be upon him), Islam has provided a clear way of how racism can be abolished. The yearly pilgrimage (Haj) to Mecca demonstrates the real Islamic brotherhood of all races and nations when about two million Muslims from all over the world come to Mecca to perform pilgrimage. Hence, one could deduce that the fact that pilgrims dress similarly in the same type of clothes during particular rituals of pilgrimage could be claimed to be one of the many ways demonstrating that all people are considered equal in Islam.

Umar Ibn Al-Khattab, the second of the four rightly-guided caliphs, (may Allah be pleased with him) was so renowned for justice that he was called 'Al-faruq', i.e., someone who distinguishes truth from falsehood. An incident that proves how just he was is the following:

Ibn Abd Al-Hakim reported: Anas (may Allah be pleased with him) said that a man from the people of Egypt came to Umar Ibn Al-Khattab and said, "O leader of the believers, I seek refuge in you from injustice!" Umar replied, "You have sought someone willing." The man said, "I competed with the son of Amr Ibn Al-'As (who was the ruler of Egypt) and I won, but he started striking me with a whip and was saying: "I am the son of the dignified!" Upon this, Umar wrote to Amr ordering him to travel to him with his son. He came with his son and Umar said, "Where is the Egyptian?" He gave him a whip and told him to strike the son of Amr. The man started striking him while Umar was saying, "Strike the son of the illiterate!" Anas said, "By Allah, the man struck him and we loved his striking, and he did not stop until we wished he stopped." Then Umar said to the Egyptian, "Direct it to Amr." The Egyptian said, "O leader of the believers, it was only his son who struck me, and I have settled the score." Umar said to Amr, "Since when did you enslave the people though they were born from their mothers in freedom?" Amr said, "O leader of the believers, I did not know about this, and he did not tell me" (Elias, 2012).

On the basis of all that is examined earlier, it could be maintained that Islam is a religion whose teachings are based on the principles of equality and freedom, and it seeks to help all mankind to live in peace.

\section{Principles of mercy and peace in Islam}

Islam attaches paramount importance to so many principles and moral values that definitely demonstrate that it is a religion of mercy to all humankind, and is keen on establishing perfect human relationships between all individuals, communities, and peoples. Some major such principles and moral values are examined below.

\subsection{Sanctity of human life}

Islam never encourages the culture of death and sadness. Conversely, it seeks to help all mankind lead a happy worldly life, and is really eager to assist them to succeed in being rewarded with a happier existence in the hereafter. Contrary to this moral principle, it is horrible that a huge number of Muslim and non-Muslim people, among whom a respectable percentage of children and women, have been killed unjustly by certain movements and organizations that claim to be Muslims and allege that the killings they have committed are for the sake of Allah. In reality, however, their deeds are but atrocious crimes that, of course, have no connection whatsoever neither with the Islamic law, nor with the behaviors of true Muslims. No wonder, killing people for no just reason implies depriving them of the right to life, the foremost right everybody must enjoy.

In Islam, the right to life - especially human life - is the most significant right. It is reckoned a sacred right that the 
Islamic state must guarantee all its citizens regardless of their religion, gender, race, color, and nationality. The sacredness of human life is emphasized in a number of Qur'anic verses. Allah, the Exalted, says, "We ordained for the children of Israel that if anyone killed a person not in retaliation of murder or for spreading mischief in the land, it would be as if he killed all mankind, and if anyone saved a life, it would be as if he saved the life of all mankind" (Qur'an, 5: 32). In another Qur'anic sura, Allah, the Almighty, warns: "Slay not the soul Allah has forbidden, except for a just cause" (Qur'an, 6: 151). The Messenger of Allah Muhammad (peace and blessings of Allah be upon him) communicated the right to life and other essential human rights in a single eloquent statement in his farewell sermon. Narrated 'Ikrima: "Ibn 'Abbas reported that the Messenger of Allah said, 'No doubt, your blood, your properties, and your honor are sacred to one another like the sanctity of this day of yours, in this town (Makkah) of yours, in this month of yours."' "The Prophet ([peace and blessings of Allah be upon him]) repeated this statement again and again."

Even in a state of war, and according to the Islamic law, Muslim fighters are strongly recommended not to kill children, women, old people, and animals; and not to cut off trees. This is clear in the Islamic Declaration on Human Rights as cited in Al-Sheha (2001). Its third article stated:

While using force, or in the event of armed fighting, it is illegal [unlawful] to kill those who do not partake a role in the actual fighting. Elderly people, women, children, wounded persons, and the sick all have the right to be treated. The captives [prisoners of war] have the right to be fed, sheltered and clothed. It is illegal to mutilate the bodies of the killed war victims. Prisoners of war must be exchanged. Families that are separated due to wars are entitled to reunite. It is forbidden to cut [or pull] trees, destroy the crops and dairy animals, and destroy buildings and other civil facilities for the enemies by shelling or blowing them up, etc.

What makes it obvious that the human self is sacred - even regarding enemies - is that, as reported by Mawdudi (1998), Islam confers particular rights on both non-combatants and combatants during wars. For the former's part, and as pointed out above, the Messenger of Allah (peace and blessings of Allah be upon him) orders: "Do not kill any old person, any child or any woman" (Abu Dawud). "Do not kill the monks in monasteries" or "Do not kill the people who are sitting in places of worship" (Musnad of Ibn Hanbal). Mawdudi (1998) reported that during a war, the Prophet saw the corpse of a woman lying on the ground and observed: "She was not fighting. How then she came to be killed?" From this statement of the Prophet the exegetes and jurists have drawn the principle that those who are non-combatants should not be killed during or after the war. With respect to the combatants' rights as recommended by the Messenger of Allah (peace and blessings of Allah be upon him) and pointed out by Mawdudi (1998), they are considered below:

- $\quad$ Prohibition of torture with fire: One of Prophet Muhammad's Hadiths reads: "Punishment by fire does not behoove anyone except the Master of the Fire" (Abu Dawud). This means that none has the right to punish with fire, except Allah. The recommendation inferred from this Hadith is that a war enemy must not be burned alive.

- Protection of the wounded: Because of the inability of the wounded to fight, or as long as they are not fighting, the Apostle of Allah prohibits attacking them.

- Prohibition of killing war prisoners: A stringent order given by Prophet Muhammad (peace and blessings of Allah be upon him) is that "no war prisoner should be put to the sword."

- Sanctity of a dead person's body: Islam stresses the sanctity of the human self whether a person is alive or dead, and even in a state of war. Contrary to what used to be practiced in the pre-Islamic eras, Islam has unequivocally forbidden Muslim fighters from mutilating the bodies of dead enemies.

- $\quad$ Returning the corpses to the enemy: This right is another proof of the sanctity of the human self in Islam. It was reported that in the Battle of the Trench, which took place in Medina in 5 AH corresponding to $626 \mathrm{AD}, \mathrm{a}$ very famous warrior among the unbelievers was killed, and his corpse fell down in the trench, which the Muslims had dug to protect their town. The unbelievers offered the Messenger of Allah (peace and blessings of Allah be upon him) ten thousand dinars requesting that their fellow's corpse be returned to them. The prophet replied that he did not sell bodies, and granted their request without having taken any money from them.

- Prohibition of looting and ruination in the enemy's country: This is clear in what has been reported about the Prophet that "[he] has prohibited the believers from loot and plunder" (Al-Bukhari; Abu Dawud), and also about Abu Bakr Al-Siddiq, the first caliph, who used to instruct Muslim soldiers while sending them to war not to destroy villages and towns, not to spoil the cultivated fields and gardens, and not to slaughter the cattle.

It is, however, worthy of note that, as Mawdudi (1998) made it clear, "the booty of war which is acquired from the battleground is altogether different from this. It consists of the wealth, provisions and equipment captured 
only from the camps and military headquarters of the combatant armies."

- Respecting treaties: Islam has strictly forbidden breaking treaties and committing treachery, in general. One of the instructions that the prophet used to give to Muslim warriors while sending them to the battlefield was: "Do not be guilty of breach of faith." This order has been repeated in the Holy Qur'an and prophetic hadiths continuously, and even if the enemy acts treacherously, Muslims should never break their promise.

\subsection{The right to religious freedom}

Certain organizations and movements in some parts of the world have been trying their utmost to impose their religious beliefs on people by diverse forms of violence, some of which are horrible crimes, such as kidnapping and killing. They also have had every intention of changing the political system of certain countries into an "Islamic" system believing mistakenly that their practices are a type of jihad, which they must do as a religious duty. Those people and every individual whatever their religion is ought to know that such practices have nothing to do with the teachings of Islam, in the sense that the right to religious freedom is underscored in several Qur'anic verses. Allah, the Almighty says, "There is no compulsion in religion" (Qur'an, 2: 256). In another sura, Allah, the Exalted, commands His Messenger Muhammad (peace and blessings of Allah be upon him) to address the disbelievers in the oneness of the only true God saying, "And I shall not worship that which you are worshipping. Nor will you worship that which I worship. To you be your religion, and to me my religion" (Qur'an, 109: 4 - 6). In another Qur'anic verse Allah addresses the Prophet saying, "Say the truth has come from your Lord: let those who wish to believe in it do so, and let those who wish to reject it do so" (Qur'an, 18: 29).

Undoubtedly, obliging people through any means to follow any religion or perform any religious duty is against human rights, and by implication it is against the Islamic law. Ali $(1996$, p.505) stated that "[men of Faith] must guard against the temptation of forcing Faith, i.e., imposing it on others by physical compulsion, or any other forms of compulsion, such as social pressure, or inducements held out by wealth or position, or other adventitious advantages." The author summed up his statement maintaining that "[forced] faith is no faith."

Additionally, it ought always to be borne in mind that even those who commit sins in public must not be aggressed by any person or punished promptly by any kind of law; they should be advised kindly to refrain from such deeds, and should be convinced gently that it is for their own benefit, and for the sake of not hurting religious people's feelings to desist from acting against religious laws.

Briefly, freedom of creed and religion is one of the basic human rights that Islam ensures every citizen enjoying it, be it Muslim or non-Muslim, in an Islamic state. Two facts justifying this are that in Tunisia, a Muslim country, Christian employees are given a paid day-off on Christmas, and that there are several thousands of Jews living in the country who enjoy all their rights exactly as Muslims do.

\subsection{Addressing people gently and treating them justly}

Many serious problems that take place between individuals, and even between close family members are due to lack of art of communication, and one aspect of lack of good communication is the use of rude language. In this respect, it is worth noting that one important Islamic characteristic of good manners that contributes to establishing good relationships between individuals and communities is addressing people politely and kindly in all situations and respecting them. Speaking to people gently is commanded in a number of Qur'anic verses. In Al-Ahzab (the Confederates) sura, Allah, the Glorious, orders: "O you who believe! Keep your duty to Allah and fear Him, and speak always the right word" (Verse 70). Allah, the Almighty, addresses His Messenger (peace and blessings of Allah be upon him) stressing the necessity of dealing with people kindly, and warning against the consequences of doing the opposite: "And by mercy of Allah, you dealt with them gently, and had you been severe and harsh-hearted, they would have broken away from about you" (Qur'an, 3: 159).

In another Qur'anic verse, Allah, the Exalted addresses His Messenger in the same context ordering: "Invite to the way of your Lord with wisdom and good admonition, and argue with them in a way that is best. Surely, your Lord knows best those who have gone astray from His Path, and knows best those who are guided" (Qur'an, 16: 125).

Addressing people kindly is stressed so much by Islam that saying good words to people and smiling at them are considered and are rewarded as acts of charity. This is demonstrated in the following prophetic Hadith:

Abu Hurairah (may Allah be pleased with him) reported that the Messenger of Allah said, "On every person's joints or small bones (i.e. fingers and toes), there is sadaqah (charity) every day the sun rises. Doing justice between two people is sadaqah; assisting a man to mount his animal, or lifting up his belongings onto it is sadaqah; a good word is sadaqah; every step you take towards prayer is sadaqah; and removing harmful things from pathways is sadaqah" (Al- 
Bukhari \& Muslim).

Islam's laying stress on addressing people in kind words implies a significant moral value consisting in respecting them and not making fun of them. Allah, glory be to Him, says, " 0 you who believe! Let not a group scoff at another group" (Qur'an, 49: 11). Commenting on this Qur'anic verse, Ali (1996, p. 1341) asserted that "mutual ridicule ceases to be fun when there is arrogance, selfishness or malice behind it. We may laugh with people to share in the happiness of life [, but] we must never laugh at people in contempt or ridicule."

Islam is very insistent upon respecting the human being, whether the person is alive or dead, and, of course, whether the person is Muslim or non-Muslim, which obviously shows the sanctity of the human self in this religion. The Messenger of Allah (peace and blessings of Allah be upon him) said, "Remember and speak well of your dead, and refrain from speaking ill of them." In a similar setting, it was reported that Prophet Muhammad commanded Muslims to stand up for funeral processions in respect for the dead person, and it was also narrated that he stood up for the funeral of a Jew for the same reason. 'Amir Bin Rabi'a narrated that the prophet said, "If anyone of you sees a funeral procession, and he is not going along with it, then he should stand and remain standing till he gets behind it, or it leaves him behind, or the coffin is put down before it goes ahead of him (Sahih Al-Bukhari; Book 23, Hadith 1308). Abdur Rahmãn Bin Abi Lailã narrated that Sahl Bin Hunaif and Qais Bin Sa'd were sitting in the City of Al-Qadisiya. A funeral procession passed in front of them and they stood up. They were told that that funeral procession was of one of the inhabitants of the land, i.e., of a disbeliever under the protection of Muslims. They said, "A funeral procession passed in front of the Prophet and he stood up. When he was told that it was the coffin of a Jew, he said, "Is it not a human being?" (Sahih Al-Bukhari; Book 23, Hadith 1312).

In the very context, in the second part of the aforementioned Qur'anic verse which reads, "nor defame nor be sarcastic to each other...," Allah commands us not to call people with offensive nicknames. The reason behind this command is that calling people with nicknames is disrespectful and hurting to them, this is why Allah makes it clear that those who do not desist from so doing are wrongdoers. In a similar respect, it was reported that the Messenger of Allah used to change people's names that had negative meanings or that might cause mockery for good, or socially-accepted ones. This shows that Islam gives crucial importance to all the individual's rights, among which is a good name. So, since a baby cannot name itself just after birth, it is the duty of its mother or father to give it a good name.

As noted earlier, one of the benefits of addressing people kindly is that it is likely to result in people's loving each other. Love is one of the most significant moral values Islam recommends among Muslims, and also between Muslims and non-Muslims. Abu Huraira reported that Prophet Muhammad (peace and blessings of Allah be upon him) said, "You will not enter paradise until you believe, and you will not believe until you love one another" (Sahih Muslim). Similarly, Anas Ibn Malik reported that the Prophet said, "None of you will have faith till he likes for his brother what he likes for himself" (Sahih Bukhari; Book 2, Hadith number 13). Commenting on this Hadith, Ash-Shaqawy (2012) contended that "if people act according to this Hadith, many deniable acts and rivalries shall end, and security, good, and peace shall prevail."

As stated in the above Hadith, love for others - Muslims and non-Muslims - is not limited only to loving them as persons for their own sake, but loving and wishing all that is good for them, and disliking all that is bad for them. Aside from this, a true Muslim's perfect behavior with others must involve the way s/he should practically deal with them. This generally lies in the obligation of treating them the way one would like them to treat him or her. This moral value is so important that Islam connects it with a person's faith and their reward (i.e., paradise or hellfire) in the hereafter as communicated in a prophetic Hadith. In point of fact, Abdullah Ibn Amr Al-Ass narrated that the Messenger of Allah said, "Whoever wishes to be delivered from the fire and enter the garden should die with faith in Allah and the Last Day, and should treat the people as he wishes to be treated by them" (Sahih Muslim; Book 020, Hadith number 4546). Notwithstanding, it ought to be borne in mind that the aforementioned true Muslim's behavior with others should not be expected to be rewarded reciprocally, in the sense that the most valuable expected reward must be on the part of Allah, not on the part of humans.

Similarly, one of the key moral values Islam underlines is that Muslims should not hate non-Muslims even if these latter hate them or harm them in one way or another. Referring to the same moral value, Ali (1996, p. 1453) asserted that "our detestation is for evil, not for men as such so long as there is a chance for repentance [....] we must give no chance to Evil for working evil on our brotherhood at any time." In a similar regard, Haneef (1995) communicated the way a true Muslim should behave with others stating that it is obligatory for him or her to live in cooperation, not competition with them, and to be helpful, kind, just and compassionate toward everybody, irrespective of whether they are of a similar or a different faith, race, culture or status, etc. Kindness to humans as well as to animals is required, for abuse against or cruelty to any of Allah's creatures is abhorrent to their Creator.

A true Muslim's behavior could be claimed to be eloquently and concisely described and recommended in a 
prophetic Hadith narrated by Oqba Ibn Amir who reported that the Messenger of Allah (peace and blessings of Allah be upon him) said, "O Oqba! Maintain ties with those who sever ties with you, give to those who deprive you, and forgive those who oppress you."

\subsection{Maintaining world peace}

As pointed out above, Islam is a religion that advocates the culture of leading a happy life. One aspect of this principle is this religion's having every intention of maintaining peace all along the globe, because conflicts lead to disastrous consequences, particularly human losses and economic depressions, which are very likely to result in very serious social problems, such as joblessness and poverty, which in turn, can be among the major causes of terrorist acts. In this context, Allah, glory be to Him, says, "But if they incline towards peace, you [Prophet] must also incline towards it, and put your trust in Allah. Verily, He is the All-Hearing, the All-Knowing" (Qur'an, 8: 61). Commenting on this Qur'anic verse, Ali (1996, p. 429) stressed the necessity that "even in the midst of the fight, we must always be ready for peace if there is any inclination towards peace on the other side. There is no merit merely in a fight by itself." Alghul (2009) noted that Islam stresses peace and reconciliation as intrinsic to all social and even international relations. He went on pointing out that as described in the Qur'an, Paradise, which is the reward for the pious, is a place of serenity; that one of the Most Beautiful ninety-nine Names of Allah is 'Salam', which means peace; and reported that throughout history, "the general approach of Muslims has been supportive of maintaining peace, spreading an environment of serenity and trust, and constructing a civilization of love, compassion, and mercy to share with other people in peace". Muslims, however, resort to military measures only in case their enemies tried to threaten maintaining peace and serenity.

\subsection{Islam is a religion of moderation}

One significant peculiarity of the peacefulness of Islam is its moderation. This is one of its distinguishing hallmarks, as opposed to excessiveness and extremism. Moderation, which in Arabic, means 'wassatiyyah', and is derived from the other Arabic word 'wassat' which signifies middle in English, is explicitly cited exactly in the middle of the longest Qur'anic sura (Al-Baqarah, i.e, the cow) that is composed of 286 verses. Allah, the Almighty, says, "Thus we appointed you a midmost nation that you might be witnesses to people, and that the Messenger might be a witness to you" (Qur'an, 2: 143).

Ezzat (2012) reported that Muslim scholars show keen interest in explaining the actual meaning of Al-wasatiyyah as it is mentioned in the Qur'anic sura 'Al-Baqarah'. He made it clear that the concept has only two meanings. The first meaning chosen by the exegetes At-Tabari and Ibn Kathir is the best and the most just. The second one denotes the fact of being just and balanced between extremism and negligence. Ezzat (2012) added that "in Arabic, it means balance or equality between two opposite things. It is also the middle of any two [contradictory] sides; not to incline to this side or to the other. There is equality between the two sides of all things". He gave an example, in this context, holding that Islam stands as the right balance between materialism and spirituality; reality and imagination; individuality and community; change and stagnation; and reason and passion.

It could, therefore, be affirmed, as alluded to earlier that those who behave wrongly under the influence of extremism, excessiveness, and extravagance are really far away from the precepts of Islam and the behaviors of righteous Muslims that abide by them. In this sense, interpreting the Qur'anic verse dealing with moderation in Islam, Ali (1996, p. 58) maintained that "the essence of Islam is to avoid all extravagances on either side. It is a sober, practical religion."

\subsection{Getting acquainted with other nations}

Islam is not a religion of isolation and introversion. On the contrary, it is a religion that is open to all the other cultures and civilizations, mainly with the object of establishing bilateral and multilateral cooperation with non-Muslim nations in all the fields of life. This actuality could be claimed to be obvious in a Qur'aic verse in which Allah, the Almighty, says: "O mankind! We have created you from a male and female, and made you into nations and tribes, that you may know one another. Verily, the noblest of you in the sight of Allah is the most pious. Truly, Allah is All-Knowing, All-Aware" (Qur'an, 49: 13).

In the above Qur'anic verse, Allah addresses all the peoples, and not only Muslims, this is why He says, "O mankind", and not "O those who believe", as is the case in many other Qur'anic verses, because of the necessity of establishing good human relationships as a universal value that is recognized and stressed by Islam, by reason of the 
various benefits all the peoples can reap from it. Doubtless, getting acquainted with one another leads to entente, and entente results in cooperation, and cooperation engenders reciprocal love, and religiously speaking, reciprocal love will be rewarded with paradise.

\section{Conclusion}

The above-examined precepts of Islam could really be claimed to be an irrefutable proof that Islam is actually keen on guaranteeing everybody all their rights, maintaining peace, and establishing good human relationships between all individuals and communities regardless of their race, gender, color, religion, social status, etc. On the other hand, the teachings of Islam examined earlier and many other ones could act as a convincing reply to those organizations and movements who have committed and may intend to commit terrorist acts or resort to any other forms of violence unjustly on behalf of Islam, and also to anti-Islamic and Islamophobic practices and attitudes on the part of non-Muslims that it is a religion of mercy to all humankind. Aside from this, it ought to be noted that what lies at the root of the criminal deeds of those who mistakenly claim to strive in the cause of Allah and the major reason behind the anti-Islamic practices and attitudes of non-Muslims is ignorance: both parties' ignorance of the essence of the true precepts of Islam, the religion whose messenger was sent as mercy to all creatures. Therefore, Muslim and non-Muslim peoples should all collaborate to achieve a universal noble aim. This consists in fighting all that nurtures terrorism and the culture of death, mainly hatred, poverty, and ignorance; and enhancing all the moral values that help humanity lead a beatific life all across the world.

\section{References}

Aberry, A. J. (1983). The Koran interpreted. Oxford: Oxford University Press.

Alghul, H. (2009). Islam as a religion of love and peace. The Fountain on Life, Knowledge and Belief, Issue 70, July - August.

Al-Hilali, M.T, \& Khan, M. M. (1998). Translation of the meanings of the Noble Qur'an in the English language. Al-Madina AlMunawwarah, Kingdom of Saudi Arabia: King Fahd Complex for the Printing of the Holy Qur'an.

Ali, A.Y. (1996). The Meaning of the Holy Qur'an (8th Ed.). Maryland, USA: Amana Publications.

Al-Khattab, N. (2008). English translation of sunan Abu Dawud. Maktaba Dar-us-Salam.

Al-Khattab, N. (2012). English translation of musnad Imam Ahmad Bin Hanbal. Maktaba, Dar-us-Salam.

Al-Sheha, A.A. (2001). Misconceptions on human rights in Islam (M. S. Dabas, Trans.). Ryadh: Islamic Propagation Office.

Ash-Shaqawy, A. (2012, April 29). Commentary on Hadith, "None of you will have faith till he wishes for his brother what he likes for himself." Retrieved from http://www. alukah.net/web/shigawi/0/40565/

Duell, M. (2014, November 30). Pope says equating Islam with violence is wrong as he calls on religion's leaders to issue global condemnation of terrorism. MailOnline. Retrieved from http://www.dailymail.co.uk/.../Pope-says-Islamist-violence-Syria-Iraqgrave-sin- against-God.html

Elias, A. (2012, July 18). Umar on freedom: When did you enslave people although they were born free? Retrieved from http://dailyhadith.abuaminaelias.com/2012/07/18/umar-ibn-al-khattab-when-did-you-enslave-people-although-they-are-born-free/

Ezzat, K. (2012, April 27). Moderation is the way of Islam. Retrieved from http://www.iccuk.org/downloads/Moderation_Is_ he _ way_of_Islam.pdf

Haneef, S. (1995). What everyone should know about Islam and Muslims. Kazi Publications.

Ibrahim, I. A. (1997). A brief illustrated guide to understanding Islam (2 ${ }^{\text {nd }}$ Ed.). Texas, USA: Darussalam Publishers and Distributors.

Iftikhar, A. (2014, August 20). Let's call ISIS "The Un-Islamic State." The Islamic Monthly. Retrieved from http://theislamicmonthly. com/lets-call-isis-the-un-islamic-state/

Khan, M. M. (1997). The translation of the meanings of sahîh Al-Bukâri. Riyadh, Kingdom of Saudi Arabia: Darussalam Publishers and Distributors.

Maududi, S.A. (1998). Human rights in Islam. Islamabad: Da'wah Academy.

Moten, A. R. (2013). Social justice, Islamic state and Muslim countries. Cultura. International Journal of Philosophy of Culture and Axiology, 10 (1), 7-24.

Muslim communities share guidelines on how to deal with cartoons. (2015, January 13). Thejournal.ie. Retrieved from www.thejournal. ie/muslim-guidelines-cartoons-published-1879154-Jan2015/

Philips, B. (2012). The true religion of God. Peace Vision.

Siddiqui, A. (2005, November 17). Translation of sahih Muslim. Retrieved from http://www.iium.edu.my/deed/hadith/muslim/

Wafy, A.A. (n.d). Human rights in Islam. Retrieved 10 April, 2015 from http://edmuslims.co.uk/Learn\%20Islam\%20-\%20Non\%20Muslims/ Islamic\%20Rights/Human\%20rights\%20in\%20lslam.pdf

What is Islam? (n.d). Retrieved 7 April, 2015 from http://www.nicheoftruth.org/pages/what_is__islam.htm 